\title{
LABELLING THE BEHAVIOUR OF PIGLETS AND ACTIVITY MONITORING FROM VIDEO AS A TOOL OF ASSESSING INTEREST IN DIFFERENT ENVIRONMENTAL ENRICHMENTS*
}

\author{
Gunel Ismayilova ${ }^{1}$, Annamaria Costa ${ }^{1}$, Ilaria Fontana ${ }^{1}$, \\ Daniel Berckmans ${ }^{2}$, Marcella Guarino ${ }^{1}$
}

\author{
${ }^{1}$ Department of Veterinary Sciences and Technologies for Food Safety, Faculty of Veterinary Medicine, \\ Università degli Studi, Via Celoria 10, 20133 Milan, Italy \\ ${ }^{2}$ Measure, Model and Manage Bioresponse (M3-BIORES), Department of Biosystems, Katholieke \\ Universiteit Leuven, Kasteelpark Arenberg 30, 3001 Heverlee, Belgium \\ •Corresponding author: gunel.ismayilova@unimi.it
}

\begin{abstract}
The aim of this study was to explore the preference and the duration of interest of weaned pigs to two different types of environmental enrichments using labelling techniques and activity monitoring. Two pens each housing 14 Dalland piglets were monitored using a video camera. The videos were labelled during the weaning phase from 30 to 60 days of age. During this time, the video recording software continuously calculated the activity index of the pigs. To detect pig exploratory and playing behaviour, a wooden block and chain enrichment were introduced into each pen for 30 days. Each video frame was manually labelled during the Day 1, 5 and 30 (24 hours a day) for each pen using the Labelling Tool software. To identify the duration and frequency of interactive episodes with environmental enrichments, pig behaviour was labelled as either: no activity, interacting with chain or interacting with the wooden block. The mean duration of interactive episodes for the chain was greater than for the wooden block $(P<\mathbf{0 . 0 0 1})$, while the frequency of interactive episodes was $\mathbf{2 8 . 8 \%}$ higher for the wooden block than for the chain. By day 5 , the mean duration of interaction episodes decreased in both pens and by day 30, only a few interaction episodes were observed. The number of interactive episodes were strictly related to the activity index and depended on the time of the day. The peaks of the mean number of interactive episodes calculated for all days of observations corresponded to the peaks of the mean activity index.
\end{abstract}

Key words: piglets, environmental enrichment, labelling, activity monitoring, camera images

Numerous scientific studies under farm conditions show that pigs tend to display the same habits and behaviour as wild pigs including foraging, playing and explorating (Wood-Gush and Vestergaard, 1991; Van de Weerd and Day, 2009). Many sci- 
entific studies have also shown that modern intensive farms compromise the natural behaviours of pigs resulting in negative social behaviours such as tail and ear biting (Meunier-Salaun et al., 1987; Fraser et al., 1991; Van de Weerd et al., 2006) and aggression towards their penmates (Kelly et al., 2000; Melotti et al., 2011).

It is widely accepted that environmental enrichments that facilitate the natural motivated behaviours of pigs improve their welfare (Wood-Gush and Beilharz, 1983; Arey, 1993; Beattie et al., 2000) and more specifically can: reduce aggressive behaviour (Grandin, 1989; Schaefer et al., 1990; Beattie et al., 1996; Melotti et al., 2011; Nowicki and Klocek, 2012); reduce belly nosing (Beattie et al., 1996; Rodarte et al., 2004; Bench and Gonyou, 2006); reduce tail biting (Bøe 1993; Petersen et al., 1995; Van der Weerd et al., 2005; Zonderland et al., 2008); and improve production performance (Beattie et al., 1995; O'Connell and Beattie, 1999; Beattie et al., 2000) and ease of handling (Day et al., 2002)

In order to enhance animal welfare on farms the EU Directive 2001/93/EC has provided a minimum standard for the protection of pigs stipulating that: "Pigs must have permanent access to a sufficient quantity of material to enable proper investigation and manipulation activities, such as straw, hay, wood, sawdust, mushroom compost, peat or a mixture of such, which does not compromise the health of the animals." However, some substrates suggested by the Directive 2001/93/EC are impractical for industrial production (Fraser et al., 1991; Van de Weerd et al., 2003). For example, large quantities of straw, hay or sawdust in standard pens with partly or fully slatted floors may block the liquid-slurry disposal systems (Van de Weerd and Day, 2009). The effective environmental enrichment provided to the pigs should not only enable the expression of relevant natural behaviours and maintain their interest, but also be practical for the existing farming systems and cost-effective for the farmers. At present, the use of point-source enrichment objects such as chains and wood blocks are a widespread alternative to disposable substrates. Point-source objects are often referred to as 'toys' and generally limited in size. Their use is often restricted to a single location in a pen (Van de Weerd and Day, 2009). Despite many scientific studies on the effect of different types of point-source objects on pigs (e.g. Bracke et al., 2006), it is still not clear which of them is most effective and what type of environmental enrichment is the most attractive to pigs and keeps their interest the longest.

The material characteristics of point-source objects play a crucial role in the interest and frequency of pigs' interactions with the object. The objects preferred by weaned and growing pigs have been characterized as 'chewable', 'deformable' and 'destructible' (Grandin, 1989; Feddes and Fraser, 1994; Van de Weerd et al., 2003) which may be linked to engaging in foraging and exploring behaviours. Some authors suggest that the combination of the enrichments are more interesting for pigs (Zonderland et al., 2003; Van de Weerd et al., 2003).

It is important that the enrichment provided is able to maintain continuous interest of the animals to minimize the risk of behaviour being redirected towards penmates (e.g. Wood-Gush and Vestergaard, 1991; Fraser et al., 1991; Bolhuis et al., 2005). However, with point-source objects, pigs can become habituated to them within a few days after introduction (Van de Weerd et al., 2003; 2009), indicating that these enrichments lose novelty and pigs' interest (Nowicki and Klocek, 2012). 
Understanding how pigs interact with enrichments over time is essential for curbing negative behaviour and promoting positive ones. Using tools to continuously monitor and quantify pig behaviour allows farmers to intervene as suitable. As stated by Cangar et al. (2008), changes in the behaviour of farm animals indicate that human intervention is necessary.

The aim of the present study was to evaluate pigs' interest and preference toward two commonly used point-source environmental enrichments (chains and wooden blocks) through monitoring their activity and labelling playing and exploratory behaviours. The methodology to evaluate animal behaviour was developed with an approach of Precision Livestock Farming (PLF). One of the objectives of Precision Livestock Farming (PLF) is to develop on-line tools for monitoring farm animals continuously and automatically during their life. The objective is to measure criteria calculated on-line from collected data without imposing additional stress to the animals. Besides on-line automatic monitoring, PLF also offers possibilities in automatic control for supporting the management of such complex biological production processes (e.g. feeding strategies, growth rate control, activity control) (Morag et al., 2001; Halachmi et al., 2002; Aerts et al., 2003 a, b; Guarino et al., 2004).

\section{Material and methods}

\section{Housing conditions and animals}

Experiments were conducted in a swine weaning building located in Pianura Padana, Pavia province, Italy. The building was naturally ventilated, containing six fully-slatted pens $(1.90 \mathrm{~m} \times 2.50 \mathrm{~m})$ located in two rows of three on either side of an access area $0.80 \mathrm{~m}$ wide. Additional lighting over the experimental pens facilitated video recording.

A total of 28 Dalland piglets (14 males and 14 females) aged 30 days and weighing an average of $13 \mathrm{~kg}$ were placed as two uniform groups into adjacent pens. The animals were fed ad libitum from a feed trough and water was available from a drinking nipple. No environmental enrichment was provided in the pen before the experiment commenced.

\section{Animal activity monitoring}

Pig activity was video recorded continuously using an infrared-sensitive CCD camera (VCB 35721RP, Sanyo Electric Co. Ltd., Osaka, Japan) for 30 days. The camera was mounted to the roof at $3.25 \mathrm{~m}$ above the pen's floor. The camera lens was placed directly above the corridor separating the two pens and connected to a PC with built-in frame grabber using the coax connection cable. Images were captured at a resolution of $768 \times 586$ pixels at a sample rate of $1 \mathrm{~Hz}$. The image analysis software Eyenamic analysed these images simultaneously in real time to create the animals' activity index - a measurement that quantifies the activity of animals in the field conditions inside the barn (Leroy et al., 2006; Bloemen et al., 1997). The activity index is determined by dividing the image of each pen into rectangular zones (Fig. 1) and tallying when pixels change between two consecutive frames within each zone. 


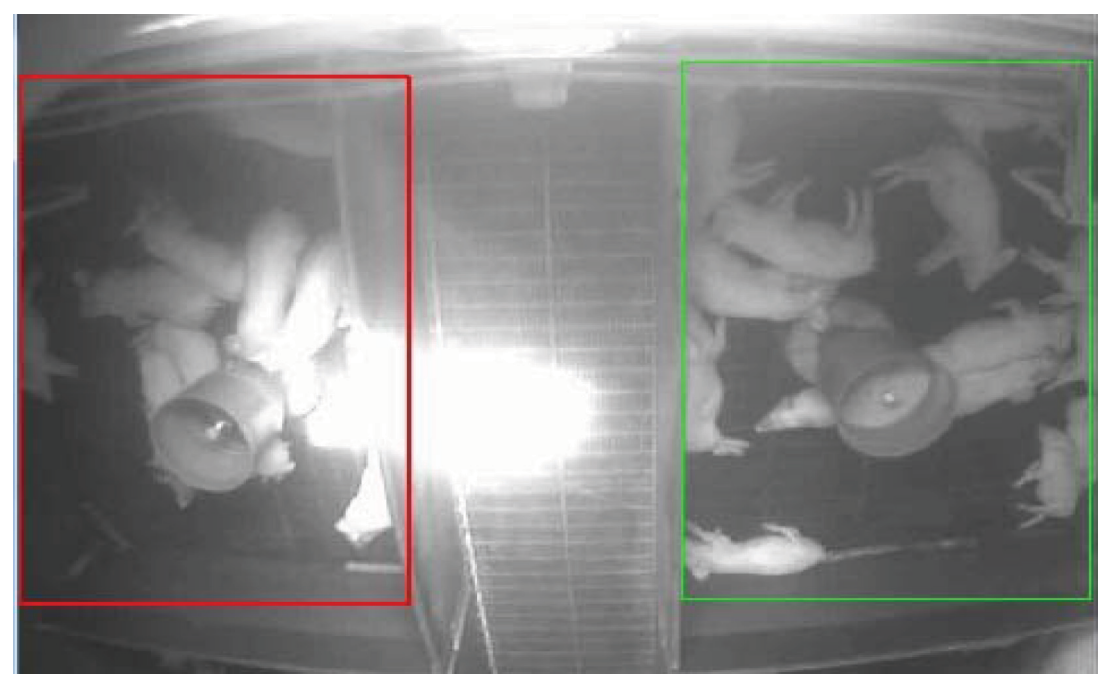

Figure 1. The two observation pens and the division of the images into areas for the activity index calculation

The software acquired a monochrome image $\mathrm{I}(x, y, t)$ from the camera and then calculated the difference between its intensity values and of the previous image $\mathrm{I}(x, y, t-1)$ taken one second earlier. From this difference image, the binary 'activity image' $\mathrm{I}_{\mathrm{a}}(x, y, t)$ was calculated by containing the pixels for which the intensity change exceeded a threshold:

$$
I_{a}(x, y, t)=\left\{\begin{array}{lc}
1 & \text { if } \mathrm{I}(x, y, t)-\mathrm{I}(x, y, t-1)>\tau_{1} \\
0 & \text { otherwise }
\end{array}\right\}
$$

From the activity image $\mathrm{I}_{\mathrm{a}}(x, y, t)$, the activity index $a_{i}(t)$ for pen $\left(Z_{i}\right)$ was calculated as the fraction of moving pixels with respect to the total number of pixels within the pen $Z i$ :

$$
a_{i}(t)=\frac{\sum_{(x, y) \in Z i} \mathrm{I}_{\mathrm{a}}(x, y, t)}{\sum_{(x, y) \in Z i} \mathrm{I}}
$$

The threshold $\tau 1$ accounted for small intensity changes due to noise, such as electrical noise in the coax cabling and image acquisition circuits, and small lighting variations. The lower threshold value was set to $10 \%$ of the maximal intensity value as estimated by looking at the intensity variation of an 'empty' region outside of the pig pen in the first 60 images (equivalent to one minute of recording).

The upper threshold $\tau_{2}$ was applied to the activity index $a_{i}(t)$ to compensate for drastic intensity changes (e.g. when lights were switched on/off). In case of such an 
event, almost all pixels in the activity image Ia were 'active' and the activity index $a_{i}(t)$ was almost equal to 1 in the two pens. The threshold $\tau_{2}$ was set to 0.5 of the maximal activity index. If this threshold was exceeded, i.e. more than half of the pen was active, the activity index was set to zero.

The pixel area sums in the nominator and denominator of equation (2) have an accuracy of one pixel which, using the camera calibration factor, was equivalent to an area of $2.9 \mathrm{~cm}^{2}$.

\section{Behaviour labelling procedure}

On 1st day of video recording, the chain and wooden block enrichments were introduced to the pens at 10:00 AM. The chain was fixed in vertical position at piglet eye level and the wooden block was placed randomly on the pen floor. The environmental enrichments were kept in the pens for 30 days. The videos of Day 1, Day 5 and Day 30 were analysed to determine the level of object-directed behaviour. These days were chosen to test the initial, short- and long-term interest of the piglets to the selected environmental enrichments.

The recorded videos were analysed by one observer using the software "Labelling Tool" (Viazzi et al., 2011) developed in Matlab (R2009a, The MathWorks Inc., MA).

The image files were visually checked and manually labelled by observing each frame (one frame per second) when the start of manipulation with the environmental enrichment was detected on the video. The labelling procedure permitted the identification of every playing/exploratory event during Day 1, Day 5 and Day 30 of the experiment for 24 hours/day (totalling 144 hours of observations for 2 pens). The observations of video recordings from Day 1 started from the moment when the enrichments were introduced to the pens. On Day 5 and Day 30, the observations started at 08:00 AM in the morning.

The recorded images were calibrated in order to define how many square centimeters in the pen correspond to a pixel. At this stage the camera images were subdivided into two equally-sized observational zones, one per pen to define zones of interest inside the video. By creating multiple zones it was possible to relate the behaviours to a specific pen. For each zone the activity index was measured from the video and displayed on the Labelling Tool interface in order to speed up the manual labelling process. If the activity was close to zero (the animals were not moving in the particular zone), the observer could leave out these intervals.

For each behaviour pattern the following specific buttons were created: no activity, interacting with chain, interacting with wooden block. Each recorded image (one image per second) was visually checked and manually labelled separately per observation zone according to the chosen behaviours of pigs through playing the video or sliding the images frame by frame. When a specific behaviour was observed in the image the matching button was selected, at the same time the labelled behaviour was displayed on the panel of Labelling Tool containing the list of behaviours. It was possible to press multiple buttons in case different playing/exploratory behaviours occur in the same image. It was also possible if the same behaviours take place in consecutive images to register their start and end by pressing the "record" button. 
The labelling procedure facilitated an exact record on the true duration of exploratory/playing behaviour, frequency and the time at which interactive episodes with each type of environmental enrichment began and ended. Interactive episodes were measured as the length of time ( $\mathrm{sec}$ ) from first touch of environmental enrichment by pig or group of pigs to termination of action for more than 5 seconds.

\section{Statistical analysis}

Data were submitted to the normality test (PROC UNIVARIATE; SAS, 2011) to evaluate the type of distribution (normal) and to identify the outliers. The variance analysis (Proc GLM, SAS 9.2, 2011) was performed on duration of exploration/ playing episodes with two types of environmental enrichments to study the effect of the day (1), time of the day (2), and environmental enrichments (3) on exploration/ playing behaviour of piglets.

Frequency analysis (Proc FREQ, SAS 9.2, 2011) was performed to determine the number of playing episodes with the two types of environmental enrichments (chain and wooden block) according to Lyons et al. (1995). To analyse the correspondence of activity index to interactive episodes, the mean frequencies of interactive episodes for Day 1 and Day 5 were merged and compared with mean activity indexes, calculated for 5 days of video recordings. All records of Day 30 were excluded as there was almost no interaction with enrichments.

\section{Results}

The duration of interaction episodes with both environmental enrichments had a similar trend in both pens. No significant difference in duration was identified; therefore, in this case, both pens were taken as one experimental unit.

The mean duration of interaction episodes was significantly greater for the chain than for the wooden block $(\mathrm{P}<0.001)$, whereas the frequency of interaction episodes was $28.8 \%$ higher for wooden block than for chain (Table 1 ).

Table 1. Least Square Means of duration (sec), frequency of interaction episodes with two types of environmental enrichments and mean day activity index of weaned piglets

\begin{tabular}{l|c|c|c|c|c}
\hline \multirow{2}{*}{ Enrichment type } & \multicolumn{2}{|c|}{$\begin{array}{c}\text { Duration } \\
\text { LSMean } \pm \text { SEM }\end{array}$} & \multicolumn{2}{c|}{$\begin{array}{c}\text { Frequency } \\
\text { Interaction }\end{array}$} & $\begin{array}{c}\text { Activity Index } \\
\text { Mean } \pm \text { SD }\end{array}$ \\
\cline { 2 - 5 } & chain & wooden block & chain & wooden block & \\
\hline Overall mean & $35.45 \pm 6.55 \mathrm{~A}$ & $20.12 \pm 4.93 \mathrm{~B}$ & 241 & 436.3 & $0,012 \pm 0.017$ \\
Day 1 & $59.79 \pm 6.45 \mathrm{~A}$ & $36.35 \pm 4.67 \mathrm{~B}$ & 423 & 663 & $0.015 \pm 0.019$ \\
Day 5 & $43.06 \pm 6.66 \mathrm{a}$ & $21.50 \pm 3.85 \mathrm{~b}$ & 298 & 643 & $0.013 \pm 0.016$ \\
Day 30 & $3.50 \pm 10$ & $2.50 \pm 4.01$ & 2 & 3 & $0.0079 \pm 0.012$ \\
\hline
\end{tabular}

A, B - least means within the same row differ for $\mathrm{P}>0.001$.

$\mathrm{a}, \mathrm{b}$ - least means within the same row differ for $\mathrm{P}>0.01$. 
Analysis of the 24-h environmental enrichment use pattern from video records showed that mean duration of interactive episodes with chain as well as with wooden block had already decreased on Day 5 and Day 30, and use had diminished to 2-3 sec with few sporadic interactive episodes (Table 1).

A time of day effect was found on interactive episodes (Fig. 2).

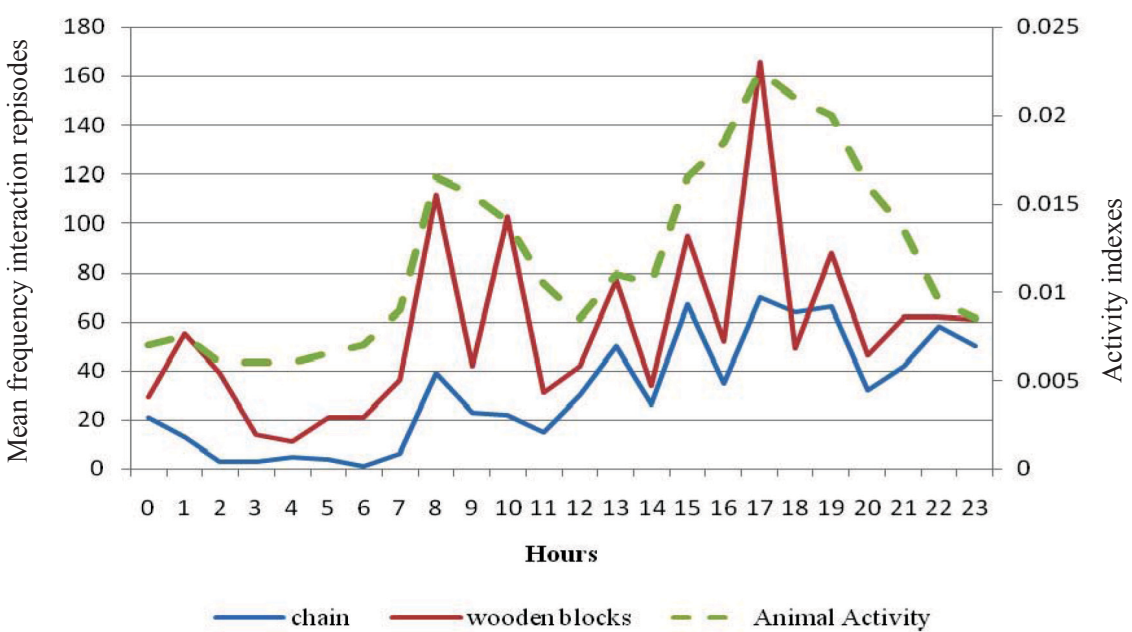

Figure 2. Effect of time of the day $(24 \mathrm{~h})$ on frequency of interaction episodes with different environmental enrichments (chain and wooden block) and animal activity

There was a drastic decline of interaction episodes frequency from 02:00 AM to 07:00 AM, which is expected as the lights were turned off during the night. Activity indexes during these hours showed the lowest values (with a range from 0.005 to 0.008 units). The peaks of activity coincided with the most frequent interactions of piglets with both types of environmental enrichments.

\section{Discussion}

The importance of environmental enrichment material properties is widely shown in literature. According to a questionnaire done by Bracke et al. (2006), the majority of pig welfare scientists believe that a chain is not sufficient enrichment material for pigs. Pigs play with chains but they prefer to play with pliable objects when they are given a choice (Grandin, 1988). However, in this study long interactions with chain were observed, even if they were not as frequent as interactions with wooden block. This could be connected to "flexibility" characteristics of the chain, the position of the chain suspended at eye level. It was found that pigs played more frequently with wooden block but the duration of playing episodes was short. Unfixed environmental enrichments (laying free on the pen floor) were less attractive for the pigs than fixed ones since they become soiled with excreta (Blackshaw et al., 1997; Jones et al., 2000; Scott et al., 2009; Nowicki et al., 2007; Nowicki and Klocek, 2012). 
However, the destructibility features of wooden block, availability in different locations within the pen and ease to manipulate them could be a reason of increased frequency use. These results suggest that the material characteristics and the position of the point-source objects are important factors influencing frequency and duration of pigs' interactions with them. The combination of the point-sourced environmental enrichments with different characteristics could be an effective solution.

The results of our experiment, in which the duration of interaction episodes with environmental enrichment is remarkably reduced with time is not surprising as they correspond with the results of other authors (e.g. Van de Weerd et al. 2003; Zonderland et al., 2003; Trickett et al., 2009; Nowicki and Klocek, 2012).

Also the time of the day influenced the frequency of interactions of pigs with environmental enrichments. The activity index showed the hours when the pigs were mostly active during the day and these peaks of activity were corresponding with hours when pigs were interacting most with environmental enrichments. This could be explained by a variety of factors influencing the general distribution of pigs activity during the day such as photoperiod, feed consumption, etc.

In conclusion, the present experiment was a preliminary study to assess the interest of the pigs in different types of environmental enrichments using the combination of the labelling method and the activity index parameter. This method enabled the specific discrimination of behaviour type and duration in order to accurately quantify the interest pigs show in environmental enrichments.

The results received from this experiment suggest that the chain and the wooden block, often used by the farmers as the low cost enrichments, are not effective for the long-term use. In case of short-term use it is advisable to combine the point-source enrichment objects with different characteristics to increase the playing time during the day.

In both pens, the number of interaction episodes with environmental enrichments were linked to the activity index, which allowed determining the diurnal behavioural dynamics of the animals.

Low cost cameras, in combination with image analysis techniques, can be used to quantify animal behaviour (De Wet et al., 2003; Leroy et al., 2004). There is a potential for the development of the algorithm for an automatic control of pigs' playing/ exploration behaviour, based on the method described in this article.

\section{References}

A erts J.-M., Lippens M., De Groote G., Buyse J., Decuypere E., Vranken E., B erc kmans D. (2003 a). Recursive prediction of broiler growth response to feed intake by using a time-variant parameter estimation method. Poultry Sci., 82: 40-49.

A erts J.-M., Van Buggenhout S., Lippens M., Buyse J., Decuypere E., Vrank e n E., B e r c k m a n s D. (2003). Active control of the growth trajectory of broiler chickens based on on-line animal responses. Poultry Sci., 82: 1853-1862.

Arey D.S. (1993). The effect of bedding on the behaviour and welfare of pigs. Anim. Welfare, 2: $235-246$. 
B e a t $\mathrm{t}$ i e V.E., Wa $1 \mathrm{k}$ e r N., S n e d d o n I.A. (1995). Effects of environmental enrichment on behaviour and productivity of growing pigs. Anim. Welfare, 4: 207-220.

B e a t t i e V.E., Walker N., S n e d d on A. (1996). An investigation of the effect of environmental enrichment and space allowance on the behaviour and production of growing pigs. Appl. Anim. Behav. Sci., 48: 151-158.

B e a t t i e V.E., O ' C on ne 11 N.E., M os s B.W. (2000). Influence of environmental enrichment on the behaviour, performance and meat quality of domestic pigs. Livest. Prod. Sci., 65: 71-79.

B e n ch C.J., Go ny o u H.W. (2006). Effect of environmental enrichment at two stages of development on belly nosing in piglets weaned at fourteen days. J. Anim. Sci., 84: 3397-3403.

B la ck s haw J.K., T ho m a s F.J., L e e J.A. (1997). The effect of a fixed or free toy on the growth rate and aggressive behaviour of weaned pigs and the influence of hierarchy on initial investigation of the toys. Appl. Anim. Behav. Sci., 53: 203-212.

B l o e m e n H., B e r c k m a n s D., A e r t s J.-M., G o e d s e e ls V. (1997). Image analysis to measure activity of animals. Equine Vet. J., 23: 16-19.

B ø e K.E. (1993). The effect of age at weaning and post-weaning environment on the behaviour of pigs. Acta Agr. Scand. A-An., 43: 173-180.

B ol hu is J.E., S chout en W.G.P., S c h r a m a J.W., W i e g a n t V.M. (2005). Behavioural development of pigs with different coping characteristics in barren and substrate-enriched housing conditions. Appl. Anim. Behav. Sci., 93: 213-228.

Bracke M.B.M., Zonderland J.J., Lenskens P., Schouten W.G.P., Vermeer H., S p o old er H.A.M., Hen driks H.J.M., Hop ster H. (2006). Formalised review of environmental enrichment for pigs in relation to political decision making. Appl. Anim. Behav. Sci., 98: $165-182$.

Cangar O., Leroy T., Guarino M., Vranken E., Fallon R., Le nehan J., Me e J., B er$\mathrm{ck} \mathrm{m}$ a n s D. (2008). Automatic real-time monitoring of locomotion and posture behaviour of pregnant cows prior to calving using online image analysis. Comput. Electron. Agr., 64: 53-60.

D a y J.E.L., S p o old er H.A.M., B urf o ot A., Cha m berla in H.L., Edwards S.A. (2002). The separate and interactive effects of handling and environmental enrichment on the behaviour and welfare of growing pigs. Appl. Anim. Behav. Sci., 75: 177-192.

De Wet L., Vranken E., Chedad A., A erts J.-M., Berckmans D. (2003). Computerassisted image analysis to quantify daily growth rates of broiler chickens. Brit. Poultry Sci., 44: 524-532.

EU Directive 2001/93/EC amending Directive 91/630/EEC laying down minimum standards for the protection of pigs.

F e d d e s J.J.R., Fra s e r D. (1994). Non-nutritive chewing by pigs: implications for tail biting and behavioural enrichment. Trans. ASAE, 37: 947-950.

Fraser D., Phillips P.A., Thompson B.K., Tennessen T. (1991). Effect of straw on the behaviour of growing pigs. Appl. Anim. Behav. Sci., 30: 307-318.

Gr a n d in T. (1988). Environmental enrichment for confinement pigs. Livestock Handling Committee. Proc. 1988 Annual Meeting, Kansas City, Missouri.

Gra n d in T. (1989). Effect of rearing environment and environmental enrichment on behaviour and neural development in young pigs. Dissertation. University of Illinois, Urbana-Campaign, IL.

Guarino M., Costa A., Van Hirtum A., Jans P., Ghesquiere K., A erts J.- M., B erc k m an s D. (2004). Field tests of an algorithm to predict infected pig coughing. Ann. Anim. Sci., Suppl., 1: 61-65.

Ha la chmi I., Metz J.H.M., Van't Land A., Ha l a chmi S., K le ijnen J.P.C. (2002). Case study: Optimal facility allocation in a robotic milking barn. Transactions of the ASAE, 45 (5): $1539-1546$.

J o n e s J.B., W a th e s C.M., W h i t e R.P., J o n e s R.B. (2000). Do pigs find a familiar odorant attractive in novel surroundings? Appl. Anim. Beh. Sci., 70: 115-126.

K elly H.R.C., B ru c e J.M., Engl is h P.R., F ow le r V.R., E d w a r d s S.A. (2000). Behaviour of 3-week weaned pigs in straw-flow, deep straw and flatdeck housing systems. Appl. Anim. Behav. Sci., 68: 269-280.

Leroy T., Vranken E., A erts J.-M., Silva M., Struelens E., Sonck B., Berckmans D. (2004). A real-time computer vision system for the quantification of animal behaviour 
and motor function. Proc. Third International Workshop on Smart Sensors in Livestock. Book of Abstracts.

Leroy T., Vranken E., Van Brecht A., Struelens E., Sonck B., Berckmans D. (2006). A computer vision method for on-line behavioural quantification of individually caged poultry. Trans. ASABE, 49: 795-802.

L y o n s C.A.P., B ru c e J.M., F ow ler V.R. (1995). A comparison of productivity and welfare of growing pigs in four intensive systems. Livest. Prod. Sci., 43: 265-274.

Melotti L., O ostindjer M., B olhu is J.E., Held S., Mendl M. (2011). Coping personality type and environmental enrichment affect aggression at weaning in pigs. Appl. Anim. Behav. Sci., 140: $137-145$.

Meunier-Salaun M.C., Vantrimponte M.N., Ra ab A., Dantzer R. (1987). Effect of floor area restriction upon performance behaviour and physiology of growing-finishing pigs. J. Anim. Sci., 64: 1371-1377.

M or a g I., E d a n Y., M a ltz E. (2001). An individual feed allocation decision support system for the dairy farm. J. Agr. Eng. Res., 79 (2): 167-176.

Nowicki J., Kopyra M., K locek C. (2007). The behavioural reaction of weaners to hanging toys: wooden ball and aromatized wooden ball - way to reduce aggression after mixing. J. Cent. Eur. Agr., 4: 447-452.

N ow i c k i J., K l o c e k C. (2012). The effect of aromatized environmental enrichment in pen on social relations and behavioural profile of newly mixed weaners. Ann. Anim. Sci., 12: 403-412.

O ' C o n n e 11 N.E., B e a t t i e V.E. (1999). Influence of environmental enrichment on aggressive behaviour and dominance relationships in growing pigs. Anim. Welfare, 8: 269-279.

P e t e r s e n V., S i m o n s e n H.B., L a w s o n L.G. (1995). The effect of environmental stimulation on the development of behaviour in pigs. Appl. Anim. Behav. Sci., 45: 215-224.

Rodarte L.F., Ducoing A., Galind o F., R o mano M.C., Vald e z R.A. (2004). The effect of environmental manipulation on behaviour, salivary cortisol and growth of piglets weaned at 14 days of age. J. Appl. Anim. Welf. Sci., 7: 171-179.

S cha efer A.L., S a lo mons M.O., Tong A.K.W., S a ther A.P., Le page P. (1990). The effect of environment enrichment on aggression in newly weaned pigs. Appl. Anim. Behav. Sci., 27: 41-52.

S c o t t K., Ta y l or L., Gi 11 B.P., E d w a r d s S.A. (2009). Influence of different types of environmental enrichment on the behaviour of finishing pigs in two different housing systems. 3. Hanging toy versus rootable toy of the same material. Appl. Anim. Behav. Sci., 116: 186-190.

S p i c e r H.M., A h e r n e F.X. (1987). The effects of group size/stocking density on weanling pig performance and behavior. Appl. Anim. Behav. Sci., 19: 89-98.

Tri c k e t t S.L., G u y J.H., E d w a r d s S.A. (2009). The role of novelty in environmental enrichment for the weaned pig. Appl. Anim. Behav. Sci., 116: 45-51.

Van de We erd H.A., D a y J.E.L. (2009). A review of environmental enrichment for pigs housed in intensive housing systems. Appl. Anim. Behav. Sci., 116: 1-20.

Van de We erd H.A., D o c k ing C.M., D a y J.E., Ave ry P.J., E d w a r d s S.A. (2003). A systematic approach towards developing environmental enrichment for pigs. Appl. Anim. Behav. Sci., 84: $101-118$

Van de We erd H.A., D o cking C.M., D a y J.E.L., B reuer K., E d w a r d s S.A. (2006). Effects of species-relevant environmental enrichment on the behaviour and productivity of finishing pigs. Appl. Anim. Behav. Sci., 99: 230-247.

Van de Weerd H.A., D o cking C.M., D a y J.E.L., E d w a r d s S.A. (2005). The development of harmful social behaviour in pigs with intact tails and different enrichment backgrounds in two housing systems. Anim. Sci., 80: 289-298.

Viazzi S., Ismayilova G., Sonoda L.T., Oczak M., Leroy T., Costa A., Bahr C., Guarino M., Fels M., Hartung J., van den Berg G., Vranken E., Berckm a n s D. (2011). Labelling of video images: the first step to develop an automatic monitoring tool of pig aggression. Proc. 15th ISAH Congress, Vienna, Austria, 3-7.06.2011.

W o o d-Gu s h D.G.M., B e il h a r z R.G. (1983). The enrichment of a bare environment for animals in confined conditions. Appl. Anim. Ethol., 10: 209-217.

Wood-Gush D.G.M., Ve st e rga ard K. (1991). The seeking of novelty and its relation to play. Anim. Behav., 42: 599-606. 
Zonderland J.J., Vermeer H.M., Ter Avest A., Vereijken P.F.G., Spoolder H.A.M. (2003). Measuring a pig's preference for suspended toys by using an automated recording technique. Proc. Int. Symp. C.I.G.R. Animal Welfare Considerations in Livestock Housing Systems, Second Technical Section, pp. 147-156.

Zonderland J.J., Wolthuis-Fillerup M., van Reene C.G., Bracke M.B.M., Ke m p B., den Hartog L.A., S poolder H.A.M. (2008). Prevention and treatment of tailbiting in weaned piglets. Appl. Anim. Behav. Sci., 110: 269-281.

Accepted for printing 2 IV 2013

\title{
GUNEL ISMAYILOVA, ANNAMARIA COSTA, ILARIA FONTANA, DANIEL BERCKMANS, MARCELLA GUARINO
}

\author{
Oznaczanie zachowania i monitorowanie aktywności prosiąt na podstawie zapisu wideo \\ jako narzędzie oceny ich zainteresowania różnymi elementami wzbogacającymi środowisko
}

\section{STRESZCZENIE}

Celem badań było sprawdzenie preferencji oraz czasu trwania zainteresowania prosiąt odsadzonych dwoma typami elementów wzbogacających środowisko kojca. Użyto do tego technik analizy obrazu oraz monitoringu aktywności zwierząt. Dwa kojce z 14 prosiętami rasy Dalland (24 prosięta) w wieku od 30 do 60 dni były monitorowane za pomocą kamery. Indeks aktywności prosiąt został obliczony podczas rejestracji nagrań wideo przez oprogramowanie do automatycznego pomiaru aktywności zwierząt. W kojcu został umieszczony na 30 dni drewniany pieniek oraz łańcuch w celu wykrycia zachowań eksploracyjnych i zabawy. Każda klatka zarejestrowanego filmu wideo została przeanalizowana w 1 ., 5. oraz 30. dniu (24 godziny na dzień) eksperymentu za pomocą oprogramowania do analizy obrazu. W celu zidentyfikowania czasu trwania i częstotliwości interakcji z elementami wzbogacającymi środowisko kojca zachowanie zwierząt zostało oznaczone jako brak aktywności, interakcja z łańcuchem lub interakcja $\mathrm{z}$ drewnianym pieńkiem. Zainteresowanie łańcuchem średnio było dłuższe $(\mathrm{P}<0.001)$ niż drewnianym pieńkiem. Częstotliwość zabawy drewnianym pieńkiem była $28.8 \%$ wyższa niż łańcuchem. Średni czas interakcji z elementami wzbogacającymi środowisko kojca uległ skróceniu w piątym dniu eksperymentu, w obu kojcach. W trzydziestym dniu eksperymentu zauważono ich tylko kilka. Liczba interakcji z elementami wzbogacającymi środowisko kojca była ściśle powiązana z wartością indeksu aktywności zarejestrowanym przez oprogramowanie i zależała od pory dnia. W każdym dniu prowadzonej obserwacji wzrost średniej liczby interakcji odpowiadał wzrostowi średniej wartości indeksu aktywności. 
